\title{
Length Frequency, Length-Weight and Relative Condition Factor of Ribbonfish, Lepturacanthus savala (Cuvier, 1829) from Karwar Waters, Karnataka State.
}

\author{
Sangita R. Kudale /Jadhav ${ }^{1}$ and J. L. Rathod ${ }^{2} *$ \\ 1. (Department of Zoology, Nowrosjee Wadia College, university of Pune. Maharashtra, India) \\ ${ }^{2}$. (*Department of Marine Biology, Karnataka University Dharwad, Post Graduate and Research Centre, \\ Kodibag, Karwar. Karnataka India)
}

\begin{abstract}
Length frequency, length-weight and relative condition factor of Ribbonfish, Lepturacanthus savala (Cuvier, 1829) from Karwar waters, Karnataka state was studied from December 2011 to December 2012 with the object of contributing additional information to the existing knowledge. Fish samples were collected monthly by random sampling method from fish landing centre Baithkol and Karwar fish market. Total 631 specimens ranging 100-630 were studied. Total length of fish was measured from tip of the lower jaw to the tip of the tail to the nearest $\mathrm{mm}$; fish were weighed nearest to 0.1 grams by using, electronic weighing balance. The length measurements were converted in to length frequencies with constant class intervals of $50 \mathrm{~mm}$. The mean lengths and weights were used for data analysis. Data for male and female fish were analysed separately. Values for ' $a$ ' and ' $b$ ' coefficients were calculated and the linear regression equations were obtained by using natural logarithmic transformations. The correlation $r^{2}$ was calculated by using linear regression analysis. The relative values for Kn was determined by using equation. Obtained values for Kn were ranged between 0.9 to 1.18 for males and 0.8 to 1.16 for females.
\end{abstract}

Keywords : Lepturacanthus savala, Length Frequency, Length-Weight relationship, Ribbon fish, Relative Condition Factor

\section{Introduction}

Ribbonfish contributes an important commercial fishery. Those are mainly caught as side catch along the Indian coast by using trawls and traditional nets. It belongs to family Trichuridae, which is most exploited pelagic fish group in India, contributes an average annual catch of 236,541 tonnes, $11 \%$ of total marine landings, (CMFRI-2012), [1]. Two species of Ribbonfish, Trichiurus lepturus and Lepturacanthus savala, dominates in the Karwar waters. The fishery is confined to the depth zone usually shallower than fifty meters (James, P.S.B.R., 1967), [2]. These fish are consumed as fresh by coastal people and also sundried without salting. Length frequency, length-weight and relative condition factor of Ribbonfish, Lepturacanthus savala (Cuvier, 1829) from Karwar waters, Karnataka state was studied from December 2011 to December 2012, Fresh samples of fish were collected monthly by random sampling method from fish landing centre Baithkol, Majali and Karwar market.

Length and weight data gives useful standard results for fish sampling programs, (Morato et. al., 2001), [3]. Knowledge of quantitative aspects such as length-weight relationship, condition factor, growth, recruitment and mortality of fishes is important for the study of fishery biology, especially for fish which are higher in the food web (Lizama and Ambrosio, 2002), [4]. According to Sinovcic et. al., (2004), [5] length weight regression have been used frequently to estimate weight from length because direct weight measurements can be time consuming in the field. Previous studies were carried out by some scientists are notable, the length-weight relationship of fish is an important fishery management tool and its importance is pronounced in estimating the average weight at a given length group (Beyer, 1987), [6]. Mendes et. al.,[7] studied weigh-length relationships of 46 fish species of the Portuguese, west coast. Pallavi, et. al., (2013), [8] studied length frequency and lengthweight of Lepturacanthus savala off Ratnagiri coast. Rizvi, A. F., (2001), [9] and Rizvi, et. al., (2002), [10] studied on two Ribbonfishes and comparison of growth in length and weight of Lepturacanthus savala and Eupleuragrammus muticus from Mumbai waters respectively.

Condition factor decreases with increase in length (Bakare, 1970), [11]. Narasimham, (1972, 1976), [12] [13] has reported condition factors of Trichiurus lepturus and Eupleuragrammus muticus from Kakinada, east coast of India. Rizvi, et. al., (2012), [14] compared condition factors of Ribbon fish, Lepturacanthus savala and Eupleuragrammus muticus from Mumbai coast. Condition factors of different species of cichlid fish have been reported by Siddique, (1977), [15]. Condition factor compares the wellbeing of a fish and is based on the hypothesis that heavier fish of a given length are in better condition (Bagenal and Tesch, 1978), [16]. According to Fagade, (1979), [17], condition factor has been used as an index of growth and feeding intensity and also 
influences the reproductive cycle in fish (Welcome, 1979), [18]. As there is no report on length frequency, length-weight and relative condition factor of Lepturacanthus savala from Karwar waters, thus present investigation was undertaken.

\section{Introduction}

\section{Material And Methods}

Uttara Kannada district has four estuarine complexes, Kali estuary, Karwar is located at $14^{\circ} 50^{\prime} \mathrm{N}$ and $70^{\circ} 07^{\prime} \mathrm{E}$. Kali estuary is subjected to greater fluctuations due to south-west monsoon and upwelling. It provides enormous food and breeding ground for the fish. Information available on various aspects of Lepturacanthus savala from Karwar waters is scanty. Therefore a detailed investigation on various aspects such as Length frequency, length -weight and relative condition factor of Ribbonfish, Lepturacanthus savala (Cuvier, 1829) from Karwar waters, Karnataka state was studied from December 2011 to December 2012, Fresh fish samples were collected monthly by random sampling method from fish landing centre Baithkol, Majali and Karwar market. During monsoon season in the months of June and July, fish were collected from shore-seine catches. Total 631 specimens ranging 100-630 were studied. Total length of fish was measured from tip of the lower jaw to the tip of the tail to the nearest $\mathrm{mm}$; fish were weighed nearest to 0.1 grams by using tabletop, electronic weighing balance.

\section{1, Length Frequency Analysis}

The length measurements were converted in to length frequencies with constant class intervals of 50 $\mathrm{mm}$. and tabulated.

\section{2, Length-Weight Relationship}

The mean lengths and weights were used for data analysis. The length and weight of fish was expressed by Le Cren's equation ( $\mathrm{W}=\mathrm{CL}^{\mathrm{n}}$ ), [19] / Pauly, (1983), [20] modified equation. $\mathrm{W}=\mathrm{a} \mathrm{L}^{\mathrm{b}}$ (Where: $\mathrm{W}=$ weight of fish in grams, $\mathrm{L}=$ total length of fish in $\mathrm{cm}$, ' $\mathrm{a}$ ' = constant and ' $\mathrm{b}$ ' = the length exponent or slope). Data for male and female fish were analysed separately. Values for ' $a$ ' and ' $b$ ' coefficients were calculated and the linear regression equations were obtained by using natural logarithmic transformations. The correlation $\mathrm{r}^{2}$, that is degree of association between the length and weight was calculated by using linear regression analysis $\left(R=r^{2}\right)$.

\section{3 , Relative condition factor $(\mathrm{Kn})$}

The condition factor $(\mathrm{K})$ was calculated by using formula $\mathrm{K}=100 \mathrm{x}$ W $/ \mathrm{L}^{3}$ (Where: $\mathrm{K}=$ Relative condition factor, $\mathrm{W}=$ weight of fish in grams, $\mathrm{L}=$ total length of fish in $\mathrm{cm}$ ), the relative values for $\mathrm{Kn}$ was determined by using equation $\mathrm{Kn}=\mathrm{W} / \mathrm{w}$ ' (Where: $\mathrm{W}=$ observed weight of the fish and $\mathrm{w}$ '= calculated weight of the fish).

\section{Results And Discussion}

The fish sample size of minimum and maximum lengths and weights were taken from December 2011 to December 2012, for thirteen months. The length measurements were converted in to length frequencies with constant class intervals of $50 \mathrm{~mm}$. The mean lengths and weights were used for data analysis. In the commercial fishery, specimens of Lepturacanthus savala were recorded in the range of 200-700 mm length (James, P.S.B.R., 1967), [2].

\section{1, Length Frequency Analysis}

During present study it was observed that, the actual specimens were ranged from 100-630 mm length. Higher number of fish caught, from the samples of commercial catches were ranged from $250-400 \mathrm{~mm}$. The first recruitment was observed in the month of April and second recruitment was observed during July- August. Maximum number of fish was found in the length frequency group 300-350 mm (24.88\%) and minimum number in $600-650 \mathrm{~mm}(0.14 \%)$, (Table-1\& Fig.1). The size distribution of Lepturacanthus savala occurring off Bombay, in the dol-net catches varied from 80-623 mm in total length. Ranges of length of male and female fish were 282-585 and 315-601 mm respectively (Rizvi, et. al., 2012), [14]. Length of the specimens of Lepturacanthus savala collected from Ratnagiri coast ranged from 100-700 mm (Pallavi, et. al., 2013), [8].

\section{2, Length-Weight Relationship}

Length- weight relationship gives information about the condition and growth patterns of fish (Bagenal and Tesch, 1978), [16]. The regression coefficient for isometric growth is' 3 ', the values greater or lesser than ' 3 ' indicate allometric growth.

For length-weight relationship, the data for males and females analysed separately and following regression equations were obtained.

$: \log W=-6.6302+3.4406 \log \mathrm{L},(1)$ and 
: $\mathbf{L o g} \mathbf{W}=\mathbf{- 6 . 4 6 0 1}+\mathbf{3 . 4 1 1 2} \log \mathbf{L}$, (2), respectively (Table2 and Table 3 ).

The ' $b$ ' values obtained from, regression line of graph for males and females were

: $3.964\left(\mathbf{R}^{2}=\mathbf{0 . 6 8 6}\right),(3)$ and

: $3.578\left(\left(\mathbf{R}^{2}=\mathbf{0 . 9 6 9}\right)\right.$, (4), respectively (Fig.2 and Fig.3).

The regression coefficient ' $b$ ' indicated that the values obtained for males and females was greater than ' 3 ', that is more in proportion to the cube of its length. It is also observed that females grow faster than males, which indicates allometric growth pattern in Lepturacanthus savala from Karwar coast. Similar results were obtained by Gupta (1967b) [21], the length-weight relationship as Log W $=-5.5396+3.3071 \log \mathrm{L}$. The exponent was found to be significantly different than '3'. Rizvi, et. al., 2012 [22], for Lepturacanthus savala collected from Mumbai coast, the equations were, $\log \mathrm{W}=-6.7808+3.01671 \log \mathrm{L}$ for male and $\mathrm{Log} \mathrm{W}=-$ $7.4918+3.4499 \log \mathrm{L}$ for female. According to Pallavi, et. al., (2013) [8], regression equations obtained for males and females of Lepturacanthus savala collected from Ratnagiri coast were Log W $=-3.2801+3.0311 \log$ $\mathrm{L}\left(\mathrm{R}^{2}=0.76\right)$ and $\log \mathrm{W}=-3.8222+3.3608 \log \mathrm{L}\left(\mathrm{R}^{2}=0.81\right)$ respectively. Length-weight gets affected by ecological factors like temperature, food supply, spawning conditions and other factors, such as age and sex, fishing time, fishing area, fishing vessels and gears also influence the length-weight relationship, (Ricker, 1973) [23].

\section{3, Relative condition factor $(\mathrm{Kn})$}

Relative condition factor was determined by length and sex wise. The study showed that there was a specific seasonal cycle in the Kn values of Lepturacanthus savala. Kn values for male (Table-4 and Figure-4), in Lepturacanthus savala were lowest (0.93, 0.96 and 0.99) in 300-350, 350-400 and 500-550 mm length group. This may be due to gonadal development and were highest 1.13 and 1.18 among 150-200 and 200-250 mm lengths, coinsided with peak spawning. This may be related to the increase in the feeding intensity of the maturing fishes as well as to build their body reserves for milting purpose. Kn value for female (Table-5 and Fig.4), in Lepturacanthus savala were minimum (0.89) in 400-450 mm, (0.86) in 250-300mm and (0.8) in 400$450 \mathrm{~mm}$ length group. This may be due to decline in feeding intensity by the spawning and spent fish and were maximum (1.16) among 150-200 $\mathrm{mm}\left(1^{\text {st }}\right.$ year $)$ and 300-350 ( $2^{\text {nd }}$ year $)$ and $(1.2)$ among $500-550 \mathrm{~mm}\left(3^{\text {rd }}\right.$ year $)$ length group, coinsided with pre-spawning period of fish. In Lepturacanthus savala during spawning period the $\mathrm{k}$ values were declined (1.04, 1.01 and 1.05 respectively). The decline of relative condition factor attributes to maturity and spawning (Gupta, 1967b) [21]. According to Gowda et, al., (1988b) [24], seasonal variation of Kn is influenced by the gonadal development, feeding activity and several other factors. Baragi (1977) [25], found it difficult to explain the changes in condition factor of some Scianid, Joneops osseus based up on the intake of food and sexual cycle. Morrow (1951) [26], found that a peak of condition factor is reached at the start of the spawning season in long horn, Sculpin which could be associated with the pre-spawning growth of the gonads. Similar trend was observed during present investigation also. Trichurus lepturus is relatively a large species reaching more than $1200 \mathrm{~mm}$ (Thiagarajan et, al., 1992) [27] while Lepturacanthus savala grows to approximately $650 \mathrm{~mm}$. During present study it was found that average growth coefficient of Lepturacanthus savala was 1.01 for males and females also. These values are higher than the values reported by. Rizvi, et. al., 2010 (0.87) [22] and Thiagarajan et, al., 1992 (0.62) [27] for Trichurus lepturus. There are no natural mortality results available for Lepturacanthus savala from Karwar coast.

\section{Figures And Tables}

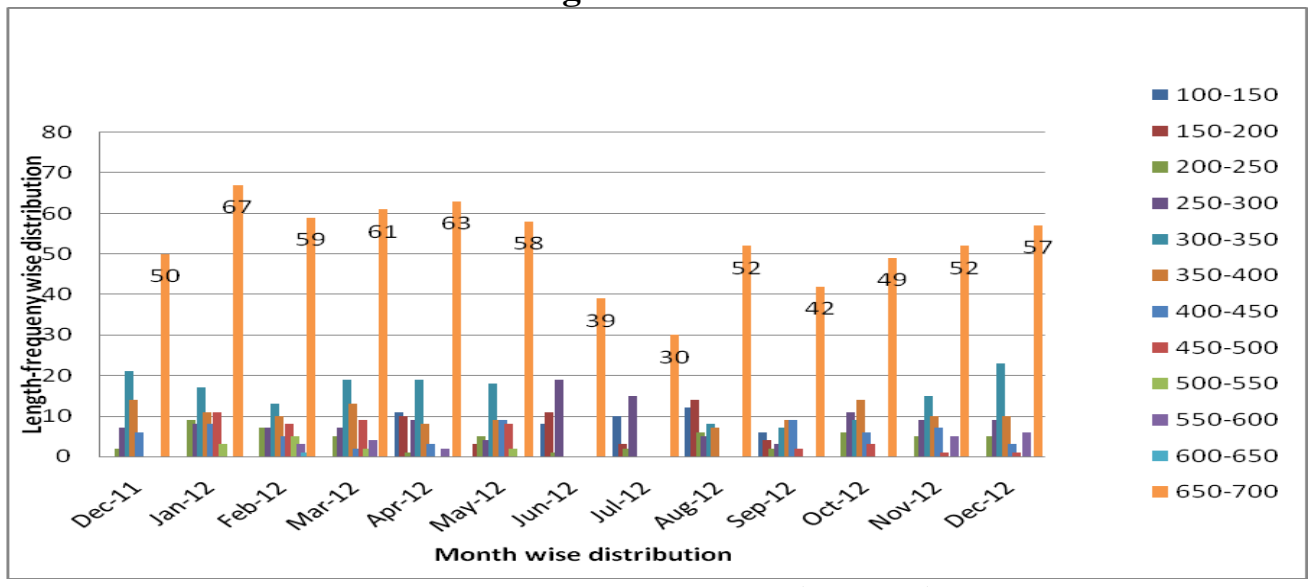

Fig.1 Month wise length frequency distribution of Lepturacanthus savala of Karwar coast during Dec.2012 to Jan. 2013 
Table -1: Month Wise Length Frequency Distribution of Lepturacanthus savala From Karwar Coast During, Dec.2012 to Jan. 2013

\begin{tabular}{|c|c|c|c|c|c|c|c|c|c|c|c|c|c|c|c|c|c|}
\hline $\begin{array}{c}\text { LENGT } \\
\text { H } \\
\text { FREQ } \\
\text { mm) }\end{array}$ & $\begin{array}{c}\text { Dec- } \\
11\end{array}$ & $\begin{array}{c}\text { Jan- } \\
12\end{array}$ & $\begin{array}{c}\text { Feb- } \\
12\end{array}$ & $\begin{array}{c}\text { Mar } \\
12\end{array}$ & $\begin{array}{c}\text { Apr- } \\
12\end{array}$ & $\begin{array}{c}\text { May } \\
12\end{array}$ & $\begin{array}{c}\text { Jun- } \\
12\end{array}$ & $\begin{array}{c}\text { Jul- } \\
12\end{array}$ & $\begin{array}{c}\text { Aug } \\
12\end{array}$ & $\begin{array}{c}\text { Sep- } \\
12\end{array}$ & $\begin{array}{c}\text { Oct- } \\
12\end{array}$ & $\begin{array}{c}\text { Nov } \\
12\end{array}$ & $\begin{array}{c}\text { Dec- } \\
12\end{array}$ & $\begin{array}{c}\text { TOTAL } \\
\text { NO }\end{array}$ & $\begin{array}{c}\text { CUM. } \\
\text { FREQ }\end{array}$ & $\begin{array}{c}\text { REL. } \\
\text { FREQ }\end{array}$ & $\begin{array}{c}\% \\
\text { FREQ }\end{array}$ \\
\hline $100-150$ & 0 & 0 & 0 & 0 & 11 & 0 & 8 & 10 & 12 & 6 & 0 & 0 & 0 & 47 & 47 & 0.0692 & 6.92 \\
\hline $150-200$ & 0 & 0 & 0 & 0 & 10 & 3 & 11 & 3 & 14 & 4 & 0 & 0 & 0 & 45 & 92 & 0.0662 & 6.62 \\
\hline $200-250$ & 2 & 9 & 7 & 5 & 1 & 5 & 1 & 2 & 6 & 2 & 6 & 5 & 5 & 56 & 148 & 0.0824 & 8.24 \\
\hline $250-300$ & 7 & 8 & 7 & 7 & 9 & 4 & 19 & 15 & 5 & 3 & 11 & 9 & 9 & 113 & 261 & 0.1664 & 16.64 \\
\hline $300-350$ & 21 & 17 & 13 & 19 & 19 & 18 & 0 & 0 & 8 & 7 & 9 & 15 & 23 & 169 & 430 & 0.2488 & 24.88 \\
\hline $350-400$ & 14 & 11 & 10 & 13 & 8 & 9 & 0 & 0 & 7 & 9 & 14 & 10 & 10 & 115 & 545 & 0.1693 & 16.93 \\
\hline $400-450$ & 6 & 8 & 5 & 2 & 3 & 9 & 0 & 0 & 0 & 9 & 6 & 7 & 3 & 58 & 603 & 0.0854 & 8.54 \\
\hline $450-500$ & 0 & 11 & 8 & 9 & 0 & 8 & 0 & 0 & 0 & 2 & 3 & 1 & 1 & 43 & 646 & 0.0633 & 6.33 \\
\hline $500-550$ & 0 & 3 & 5 & 2 & 0 & 2 & 0 & 0 & 0 & 0 & 0 & 0 & 0 & 12 & 658 & 0.0176 & 1.76 \\
\hline $550-600$ & 0 & 0 & 3 & 4 & 2 & 0 & 0 & 0 & 0 & 0 & 0 & 5 & 6 & 20 & 678 & 0.0294 & 2.94 \\
\hline $600-650$ & 0 & 0 & 1 & 0 & 0 & 0 & 0 & 0 & 0 & 0 & 0 & 0 & 0 & 1 & 679 & 0.0014 & 0.14 \\
\hline $650-700$ & 50 & 67 & 59 & 61 & 63 & 58 & 39 & 30 & 52 & 42 & 49 & 52 & 57 & & & & \\
\hline
\end{tabular}

Table- 2: Length-Weight Relationship in Males of Lepturacanthus savala

\begin{tabular}{|c|c|c|c|c|c|}
\hline $\begin{array}{c}\text { Avg. } \\
\text { length } \\
\text { (mm) }\end{array}$ & $\begin{array}{c}\text { Mid } \\
\text { point }\end{array}$ & $\begin{array}{c}\text { Avg. } \\
\text { weight } \\
\text { (grams) }\end{array}$ & Log length & $\begin{array}{c}\text { log } \\
\text { weight }\end{array}$ & $\begin{array}{c}\text { log length } \\
\text { x log } \\
\text { weight }\end{array}$ \\
\hline $100-150$ & 125 & 61.2 & 2.0969 & 1.7867 & 3.7465 \\
\hline $150-200$ & 175 & 68.3 & 2.243 & 1.8344 & 4.1145 \\
\hline $200-250$ & 225 & 81.81 & 2.3521 & 1.9128 & 4.499 \\
\hline $250-300$ & 275 & 96.85 & 2.4393 & 1.986 & 4.8444 \\
\hline $300-350$ & 325 & 124.5 & 2.5118 & 2.0951 & 5.2624 \\
\hline $350-400$ & 375 & 197.2 & 2.574 & 2.2949 & 5.907 \\
\hline $400-450$ & 425 & 211.3 & 2.6283 & 2.3248 & 6.1102 \\
\hline $450-500$ & 475 & 202.4 & 2.6766 & 2.3062 & 6.1727 \\
\hline $500-550$ & 525 & 219.9 & 2.7501 & 2.3422 & 6.4412 \\
\hline $550-600$ & 575 & 227.1 & 2.7596 & 2.3562 & 6.5221 \\
\hline $600-650$ & 625 & 335.6 & 2.7958 & 2.5258 & 7.0616 \\
\hline & 375 & 166.0145 & 2.5297 & 2.16 & 5.5165 \\
\hline
\end{tabular}

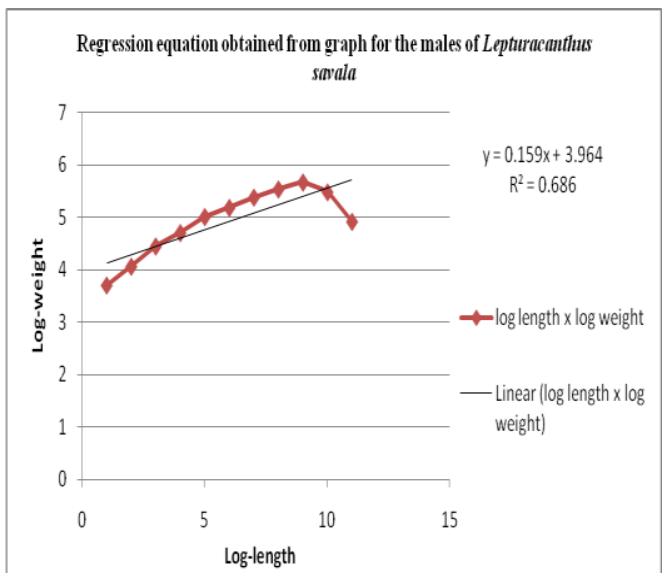

Fig.2-Length-weight relationship in males of Lepturacanthus savala

Table- 3: Length-Weight Relationship in females of Lepturacanthus savala

\begin{tabular}{|c|c|c|c|c|c|}
\hline $\begin{array}{c}\text { Avg. } \\
\text { length } \\
\text { (mm) }\end{array}$ & $\begin{array}{c}\text { Mid } \\
\text { point }\end{array}$ & $\begin{array}{c}\text { Avg. } \\
\text { weight } \\
\text { (grams) }\end{array}$ & Log length & $\begin{array}{c}\text { Log } \\
\text { weight }\end{array}$ & $\begin{array}{c}\text { log length } x \\
\text { log weight }\end{array}$ \\
\hline $100-150$ & 125 & 58.2 & 2.0969 & 1.7649 & 3.7008 \\
\hline $150-200$ & 175 & 64.6 & 2.243 & 1.8102 & 4.0602 \\
\hline $200-250$ & 225 & 77.8 & 2.3521 & 8.8909 & 4.4475 \\
\hline $250-300$ & 275 & 84.85 & 2.4393 & 1.9286 & 4.7044 \\
\hline $300-350$ & 325 & 98.98 & 2.5118 & 1.9955 & 5.0122 \\
\hline $350-400$ & 375 & 103.57 & 2.574 & 2.0152 & 5.1871 \\
\hline $400-450$ & 425 & 111.8 & 2.6283 & 2.0484 & 5.3838 \\
\hline $450-500$ & 475 & 117.42 & 2.6766 & 2.0697 & 5.5397 \\
\hline $500-550$ & 525 & 121.8 & 2.7201 & 2.0856 & 5.673 \\
\hline $550-600$ & 575 & 129.71 & 2.7596 & 2.1129 & 5.485 \\
\hline & 350 & 96.87 & 2.50017 & 2.67219 & 4.91937 \\
\hline
\end{tabular}

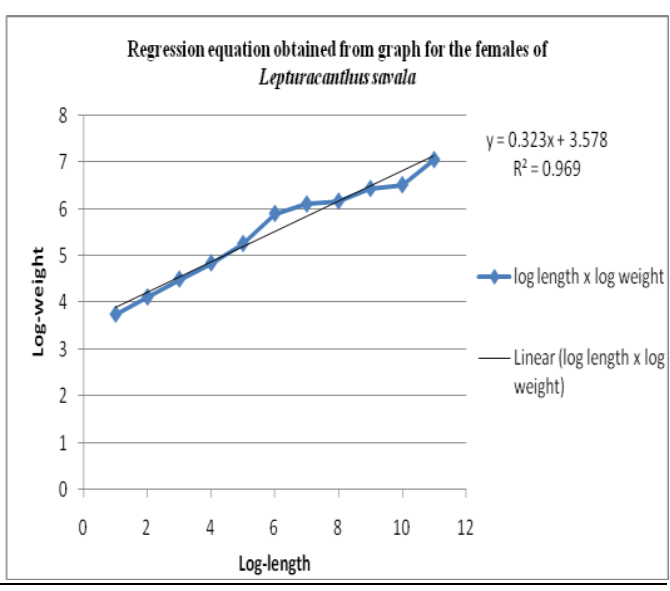

Fig.3-Length-weight relationship in females of Lepturacanthus savala 


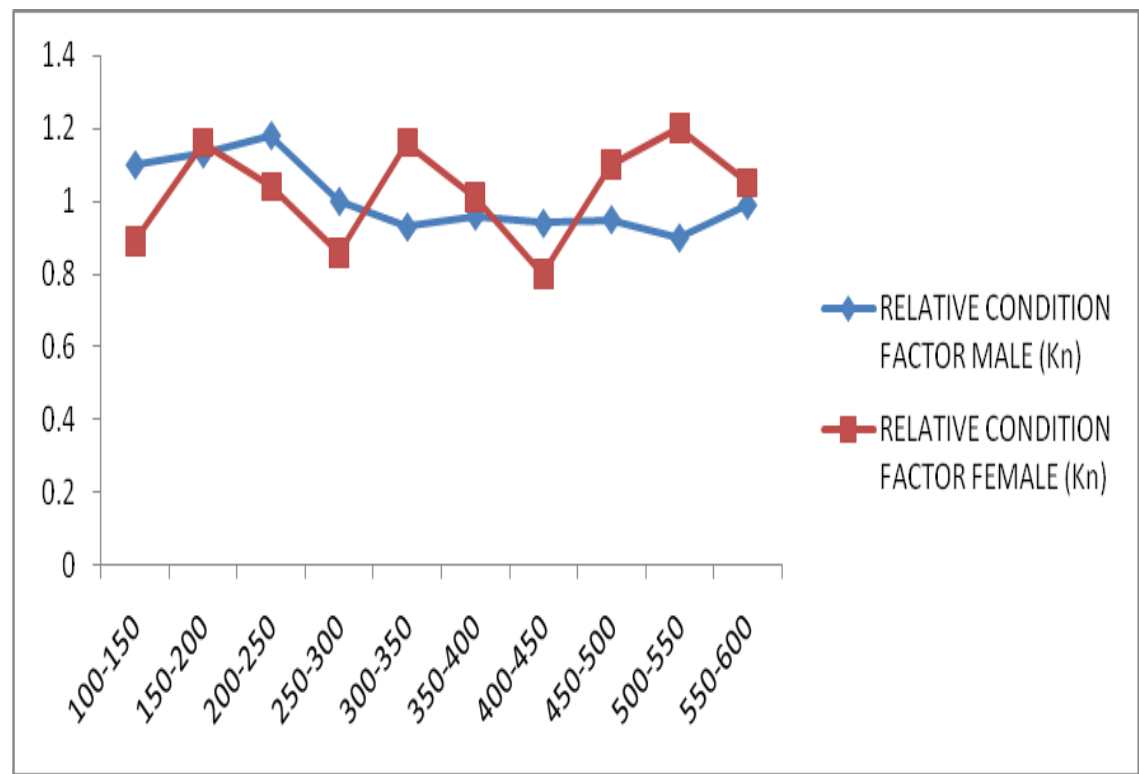

Fig. 4-Relative condition factor (kn) values for different length groups in Lepturacanthus savala (male and female)

Table - 4: Length-Weight Relationship and Relative Condition Factor in Male Lepturacanthus savala

\begin{tabular}{|l|r|l|r|r|}
\hline $\begin{array}{l}\text { LENGTH } \\
\text { GROUPS(mm) }\end{array}$ & $\begin{array}{l}\text { MEAN } \\
\text { LENGTH(mm) }\end{array}$ & $\begin{array}{l}\text { lBSERVED (W), } \\
\text { grams }\end{array}$ & $\begin{array}{l}\text { CALCULATED } \\
\text { WEIGHT (W'), } \\
\text { grams, }\end{array}$ & $\begin{array}{l}\text { RELATIVE } \\
\text { CONDITION } \\
\text { FACTOR(Kn)=W/W' }\end{array}$ \\
\hline $100-150$ & 125 & 58.2 & 52.2 & 1.1 \\
\hline $150-200$ & 175 & 64.6 & 56.4 & 1.13 \\
\hline $200-250$ & 225 & 77.8 & 65.58 & 1.18 \\
\hline $250-300$ & 275 & 84.85 & 84.6 & 0.93 \\
\hline $300-350$ & 325 & 98.98 & 106 & 0.96 \\
\hline $350-400$ & 375 & 103.57 & 107.19 & 0.94 \\
\hline $400-450$ & 425 & 111.8 & 117.75 & 0.95 \\
\hline $450-500$ & 475 & 117.42 & 122.33 & 0.9 \\
\hline $500-550$ & 525 & 121.8 & 134.11 & \\
\hline
\end{tabular}

Table - 5: Length-Weight Relationship and Relative Condition Factor in Female Lepturacanthus savala

\begin{tabular}{|c|c|c|c|c|}
\hline $\begin{array}{l}\text { LENGTH } \\
\text { GROUPS(mm) }\end{array}$ & $\begin{array}{l}\text { MEAN } \\
\text { LENGTH }(\mathrm{mm})\end{array}$ & $\begin{array}{l}\text { MEAN WEIGHT, } \\
\text { OBSERVED (W), grams }\end{array}$ & $\begin{array}{l}\text { CALCULATED } \\
\text { WEIGHT(W'), } \\
\text { grams, }\end{array}$ & $\begin{array}{l}\text { RELATIVE CONDITION } \\
\text { FACTOR }(\mathrm{Kn})=\mathrm{W} / \mathrm{W},\end{array}$ \\
\hline $100-150$ & 125 & 61.2 & 68.65 & 0.89 \\
\hline $150-200$ & 175 & 68.3 & 58.54 & 1.16 \\
\hline $200-250$ & 225 & 81.81 & 78.14 & 1.04 \\
\hline $250-300$ & 275 & 96.85 & 112 & 0.86 \\
\hline $300-350$ & 325 & 124.5 & 91.31 & 1.16 \\
\hline $350-400$ & 375 & 197.2 & 195.2 & 1.01 \\
\hline $400-450$ & 425 & 211.3 & 263.3 & 0.8 \\
\hline $450-500$ & 475 & 202.4 & 180.92 & 1.1 \\
\hline $500-550$ & 525 & 219.9 & 171.4 & 1.2 \\
\hline $550-600$ & 575 & 227.1 & 215.5 & 1.05 \\
\hline $600-650$ & 625 & 335.6 & 359.6 & 0.93 \\
\hline
\end{tabular}

\section{Conclusion}

From the foregoing study it is obvious that our knowledge about various aspects of Lepturacanthus savala is considerable and it would be of interest. Among the Ribbon fish species Lepturacanthus savala is widely distributed and accounting for bulk of landings. This species was studied to fill up the gapes in our 
knowledge and will help to evolve suitable management policy. Regular monitoring of the Ribbon fish fishery should be undertaken.

\section{Acknowledgments}

The authors express gratitude to Dr. U. G. Bhat, and Dr. Kusuma Neelakantan, former chairmen's, Department of Marine Biology, K. U. P. G. Centre, Karwar, for their constant support and valuable guidance.

References
[1] CMFRI, Annual report of Central Marine Fisheries Research Institute, Kochi, Kerala, 2012.

[2] James, P.S.B.R., The ribbon fishes of the family Trichuridae of India. Memoir 1. Marine Biological Association of India 1967, 226.

[3] Morato, T., Afonso, P., Loirinho, P., Barreiros, J. P., Sanstos, R. S. and Nash, R. D. M..Length weight relationships for 21 coastal fish species of the Azores, North-Eastern Atlantic. Fisheries Research, 50, 2001, 297-302.

[4] *Lizama, M.D.A.P., And A.M. Ambrosio. Condition factor in 9 species of fish of the Characidea family in the upper Parana River floodpiain, Brazil. Braz. J. Biol., 62 (1), 2002.

[5] Sinovcic,G., Franicevic, M., Zorica, B.and Ciles-Kec, V. Length-weight and length-length relationship for 10 pelagic fish species from the Adriatic Sea(Croatia).J. of applied Ichthyology., 20, 2004, 156-158.

[6] Beyer, J. E.,On length-weight relationship computing the mean weight of the fish of a given length class fish. byte, 5(1), 1987, 11-13.

[7] Mendes, B., Fonseca, P. and Campos, A. Weight-length relationships for 46 fish species of the Portuguese, west coast. J.of Applied. Icht., 2004, 355-361.

[8] Pallavi, K. Pakhmode, Swapnaja, A. Mohite, Suresh, D. Nike, Ashish, S. Mohite., Length frequency analysis and length-weight relationship of Lepturacanthus savala (Cuvier,1829) off Ratnagiri coast, Maharashtra. Int. nat. j. of fisheries and aquatic sciences 2013; 1, 2013, 25-30.

[9] * Rizvi, A. F. Studies on two ribbonfish from Mumbai waters. Ph. D. Thesis. University of Mumbai, $2001,305$.

[10] Rizvi, A.F. and Nautiyal, P. Landing and exploitation pattern of ribbonfish from Mumbai Coast. Hima. J. Envi. Zoo., 2002, 95-102.

[11] *Bakare, O., Bottom deposits as food of inland fresh water fish. In; Kainji, A Nigerian man-made lake. $S$. A.Visser, (Ed). Kanyi Lake studies Vol. 1. Ecology Published for the Nigerian Institute, 1970.

[12] Narasimham, K.A. On the length weight relationship and relative condition factor in Trichiurus lepturus (Linnaeus) Ind. J. Fish., 1972, 90-96.

[13] Narasimham, K.A. Some observations on the biology of the ribbon fishes, Eupleurammlus muticus (Grey). Ind. J. Fish.1976, 494-497.

[14] Anees F. Rizvi, V. D. Deshmukh and Chakraborty. Comparison of condition factor of the ribbonfish, Lepturacanthus savala (Cuvier, 1829) and Eupleurogrammus muticus (Grey, 1831) from Mumbai coast. J. Mar. Biol. Ass. India, 54 (1), 2012, 26-29.

[15] Siddique, A.Q. Reproductive biology, length-weight and relative condition of Tilapia leucostica (Trewaeva in lake Naivasha, Kenya) J. Fish. Biol., 1977, 351-360.

[16] *Bagenal, T.B. and A. T. Tesch., Conditions and growth patterns in fresh water habitats. Blackwell Scientific Publications, Oxford., 1978.

[17] Fagade, S. O., Observations of the biology of two species of Tilapia from Lagos lagoon Nigeria. Bull. Inst. Fond. Afr. Nore., (ser. A) 41, 1979, 627-658.

[18] Welcome, R. L., Fisheries ecology of food plain rivers. London long man press. 1979, 317.

[19] Le Cren, E. D., The length-weight relationship and seasonal cycle in gonad weight and condition in perch, Perca fluviatilis. J. Anim. Ecol., 20(2), 1951, 201-219.

[20] Pauly, D. Some simple methods for assessment of tropical fish stock. FAO Fish Tech., 1983, $234: 52$.

[21] Gupta, M.V. Studies on taxonomy, biology and fishery of ribbon fishes (Trichuridae) of the Hooghly estuarine system. 2. Biology of Lepturacanthus savala (Cuvier), lbid. 20, 1967b, 153-170.

[22] Rizvi, A.F., Deshmukh, V.D., Chakraborty, S.K. Stock assessment of Lepturacanthus savala (Cuvier, 1829) along north-west sector of Mumbai coast in Arebian Sea. Ind. J. Fish. 57, 2010. (2), 1-6.

[23] Ricker, W. E. Linear regressions in fishery research. J. of Fisheries Research Board of Canada. 1973, 409-43.

[24] Gowda, H. H.; Joseph, P. S. and Joseph, M. M. Growth, Condition and Sexuality of the Indian Sandwhiting, Sillago sihama (Forskal); [In: The First Indian Fisheries Forum, Proceedings; (Ed.): Joseph, M. M.]; Asian Fisheries Society, Indian Branch; 1988b, 229-232.

[25] Baragi, V.M. Biology of Johnieops osseus (Day) with notes on the Scianid fishery of the South Kanara coast. M. F. Sc. Thesis. University of Agricultural Sciences, Bangalore, 1977, 1-92. 
[26] *Morrow, J. E. Jr. Studies on the Marine Resources of Southern New England, VIII. The Biology of the Longhorn Sculpin, Myoxocephalus octodecimspinocus; Mitchell 1. With a Discussion of the Southern New England "Trash" Fishery; Bull. Bingh. Ocean; 13(2):1-89, 1951, 255.

[27] Thiagarajan, R.S., Lazarus, Y., Appanasastry, M.Z., Khan, N., Kasim, H and Scariah, K. S., Stock assessment of the ribbonfish, Trichurus lepturus (Linnaeus), from the Indian waters. Ind. J. Fish.1992, 182-194. 